\title{
The Optimization of Folklore in Literature Learning as a Strengthener of Student Literacy Culture
}

\author{
Zuliyanti $^{1}$ and Mukh Doyin ${ }^{2}$ \\ \{ ${ }^{1}$ zuliyanti@mail.unnes.ac.id, ${ }^{2}$ mukhdoyin@gmail.com\} \\ ${ }^{1,2}$ Universitas Negeri Semarang
}

\begin{abstract}
The existence of folklore as oral literature has been potentially eliminated of students. Student interest in learning and preserving has decrease. However, folklore as a cultural wealth of nations contains of noble values that should be inherited and preserved to the younger generation. The problem in this research is how to optimize folklore in literary learning as supporter of cultural literacy among students. The research method is a qualitative descriptive. The data of this study are folklore from Kudus. The data collection techniques and the research instruments are interview guides, observation sheets, data cards, and documentation files. The data analysis technique was carried out by qualitative techniques, namely reduction, data processing, data presentation, and conclusion. The introduction and preservation of folklore can be conducted by optimizing in literary learning as a learning resource. This optimization can be a reinforcement of the younger generation character and cultural literacy (reading and writing). This condition focuses on the declining of cultural literacy of students. Folklore as a fictional story can be presented with interesting language and not boring so that it can foster readers' interest to write and read. The strengthening of cultural literacy begins with having interest in reading then continues with writing. Thus, the optimizing of folklore is needed especially in the literary learning as a supporter of cultural literacy for young generations who are superior, creative and innovative.
\end{abstract}

Keywords: folklore, literature learning, literacy culture

\section{Introduction}

Folklore as oral literature has great potential to be eliminated or even extinct from the community if no one learns or preserves it. This condition can also be found among students. Many students know folklore that developed in Indonesia. In fact, if it is examined deeply, folklore contains noble values that should be inherited and preserved to future generations, especially for adolescents. The existence of moral values in folklore is expected to be able to bring up positive values for the reader, so students are considerate to problems related to social life and encourage to have good behavior [1]. Folklore values contribute greatly in maintaining the continuity of community life, supporting good personalities and characters, and can strengthen national cultural resilience. 
The crucial role of folklore in character building is not yet in line with its existence in the community, especially among students. Folklore still gets minimal portions and underestimated. Thus, it is needed the optimizing among students by integrating it in literature learning. This optimization can be implemented by using folklore as a learning resource or teaching material in literature learning.

Literature learning can encourage the learning community to maintain traditional values, cultural identity, and the local knowledge accumulation that is expected to grow, develop, and interact with energy intake from external sources [2]. The statement provides reinforcement that literature learning teaches about cultural values which are being the national identity that is also contained in folklore. Thus, folklore has the potential to be optimized in literature learning. In addition to be a strengthener of the nation, folklore can also be optimized as a literacy culture strengthener. The problem of literacy in Indonesia is still being a big problem that must be immediately overcome and resolved with appropriate solutions. Literature learning still gets a low portion, especially in literature learning. This condition correlates with the low quality of literature learning so that it has an impact on the decline of literacy culture among students. Strengthening literacy should be revived because someone who is capable in literacy is not only able to read and write but will also support someone to think critically [3].

Literature learning has great potential to strengthen literacy culture because literary texts tend to be interesting to read or write if it is compared to linguistic texts [4]. Likewise, folklore that can be enjoyed with oral expressions with the right style, expression, rhythm, and tone that will be able to bring literature more expressive for the audience. Although folklore as oral literature, but it will actually be interesting to write. If folklore has been inventoried or used as a learning resource, it can also be an interesting material to read. The use of folklore as teaching material in the literature learning will be able to arouse the audience interest to write and read it. Based on these problems, it is urgent to implement the optimizing of folklore in literature learning as a strengthener of literacy culture, especially for the next generation of the nation.

\section{Research Method}

The research method used is descriptive qualitative research. The data of this research are folklore from Kudus, Jepara, and Demak. The data collection techniques are interview, observation, note taking, and documentation. The instruments used are interview guides, observation sheets, data cards, and documentation files. The data analysis technique was carried out by using qualitative techniques, namely reduction, processing, presentation of the data, and conclusion.

\section{Results And Discussion}

\subsection{Folklore}

Folklore is oral literature which is spread in a community and contains many values of life. Folklore is formed from the word of folk which means a group of people who have physical, social, and cultural identification characteristics so that they can be distinguished from other groups. While lore is a tradition. Folklore is a part of culture which is inherited orally only [5]. 
Folklore is a part of a collective culture, which is spread and inherited from generation to generation, by any type of collective, traditionally in different versions, both in oral form or in examples accompanied by gestures or mnemonic device. Folklore is a self reflection and human habit collectively, so by revealing folklore as well as looking for human identity [6]. In other words, folklore is a culture that is inherited to a group of people orally.

Folklore can be divided into three major groups, namely oral folklore, partly verbal folklore, and nonverbal folklore [5]. Oral folklore is interpreted as purely oral folklore. The forms of this folklore including (a) folk speech such as accent, nickname, traditional position, and title of nobility; (b) traditional expressions, such as proverbs, sayings, and bywords; (c) traditional questions, such as puzzles; (d) folk poetry, such as poem, gurindam, and poetry; (e) folk prose stories, such as myths, legends, and fables; (f) people's songs. Partly oral folklore is interpreted as folklore that is formed by a mixture of verbal and non-verbal elements. The forms include beliefs, folk games, folk theater, folk dances, customs, ceremonies, folk parties, and others. Nonverbal folklore is defined as folklore in the form of nonverbal form, even though the method of its creation is taught orally. It can be concluded that the form of folklore is not verbal, but material and not material. Materials include folk architecture, handicrafts, food and drinks, and traditional medicines. On the other hand, those that are not material include traditional gestures, sound signals for public communication, and folk music.

\subsection{Folklore in Literature Learning}

Literature learning is actually part of Indonesian language and literature learning. To date, literature learning has not been able to take place to the maximum or in other words has not yet got a special impression of students. It is no wonder because most students are not all able to enjoy and understand literature more deeply.

Literature is a fiction, a person's creation as an expression of his appreciation into the form of language [7]. As a literary work that use language as its media, literature is very priority and loyal to life, to humans, and to language [8]. However, there is another statement who stated that literature is not only the language used as its media, but literature is considered as a complex statement and knowledge about the world of writers and readers [9].

Literature has a big influence on people think about life. Good and bad, right and wrong, and the way of life of people and its nation [10]. In other words, literature is able to provide a variety of high value satisfaction, which is not obtained by other means [9]. However, the problem that occurs at this time is that not all literary works have been well known or even understood by the community. Literary works that develop and are close to local people's life are folklore. Each region developed folklore, but there are also many areas where the community did not know it. The type of folklore which is included as oral literature has the potential to disappear or extinct if it is not learned. Therefore, folklore needs to be revived and preserved by optimizing through literature learning.

Literature learning can mechanically achieve learning abilities, namely affective, cognitive, and psychomotor abilities. Affective ability is a basic human ability related to someone's emotional. Cognitive abilities are abilities of humans based on thought. Psychomotor ability is the ability to regulate the mental side to withstand various problems. These three abilities can simultaneously be found in the literature teaching [11].

Literature learning requires varied learning resources obtained from various sources, one of them is folklore. Folklore includes oral literature which contains cultural values as historical heritage from generation to generation. Folklore contains messages to be conveyed to the community in the form of meaning and function, values, and norms as well as local wisdom. Folklore can be explored through various local cultural wisdoms about the value of 
policy, honesty, fairness, togetherness, and others [6]. Thus, folklore can be used as an appropriate media to introduce and teach the values of life and culture to students.

Foklor has four functions, namely (1) as a projective system such as a means of reflecting the imagination of a collective, (2) as a media of ratifying institutions and cultural institutions, (3) as an educational tool (pedagogical device), and (4) as a coercive and supervisory tool so that community norms will always be obeyed by their collective members [12]. The statement means that folklore has an important function in education. The learning resources in literature learning can be used in the content of folklore as a learning material. This is very helpful for students to be able to understand literature because there are many folklores that develop in the area where students live.

Folklor as a learning resource in literature learning can stimulate the thoughts, feelings, attention, and individuals interest to be involved in the learning process. Folklore can represent the provision of information clearly and attractively from the messenger (lecturer) to the recipient of the message (students) so that the learning communication objectives can be achieved optimally. The use of folklore as a teaching material in literature learning also plays a role in preserving local culture by introducing folklore from the student's area and teaching the values and norms of life that come from the folklore story. This is based on the decrease of people interest of their own culture which is correlated with the decrease of the local culture spread to the young generation. Thus, folklore as a learning resource can play a role in preserving local wisdom and fostering students' interest of literature.

\subsection{Folklore as a Strengthener of Literacy Culture}

The big challenge currently faced by the Indonesian people is the decrease of the literacy culture among students. It can be seen in the difficulty of neglecting the oral tradition and entering the literacy tradition [13]. Some people prefer talking to writing, prefer listening to reading. Whereas, someone who is capable of literating is not only able to read and write but will also support someone to think critically [3].

Literacy (reading and writing) is also interpreted as the "heart" of education because in literacy it contains of information, science, and knowledge, as well as messages or values of noble life that are able to create personal character [3]. Literacy competence does not only cover reading and writing activities. Nowadays, literacy has a very broad meaning. Referring to the statement, literacy can be interpreted as the ability to read and write that is closely related to Indonesian language learning.

Literature learning is more emphasized on the ability of information that refers to several activities, namely gathering information, processing information, and communicating information [14]. These activities can not be separated from reading and writing activities. Talking about literacy learning, Axford in [2] also said that one of the goals of literature learning is to help students to understand and find effective strategies in terms of reading and writing skills, including the ability to interpret complex text meanings in grammatical and syntactic structures. The purpose of literacy learning generally is to provide reading and writing skills for students as a form of real experience [14].

Literature ability is an important ability that must be mastered by students in order to master competencies in other subjects. It is clear that literacy is not limited to cognitive abilities, but rather complex abilities because it includes social aspects, linguistic aspects, and psychological aspects. Literacy abilities can be developed by studying folklore in literature learning. Literature with the characteristics of its language that is pleasant to read and not boring can foster enthusiasm for its readers. The information and intention obtained by students from reading or writing folklore is important. 
The habit of studying folklore through reading and writing activities will familiarize students with literacy activities. This is based on the nature of literature that is interesting to read than reference books lectures. The joy of literary work is expected to be the beginning of increasing the interest for reading and writing activities which in turn develops the literacy culture among students.

Efforts to habituate in literacy according to [14] are categorized into two, namely (1) habituation through the development or creation of literacy culture and (2) habituation through learning in various subjects. The purpose of the activity is the same, namely to increase the habit of reading and writing of students. However, on the other hand, there is a need for cooperation and support from the use of media and learning resources that are varied and adapted to the needs of students when the literature learning process occurs.

\section{Conclusion}

Folklore as oral literature has great potential to be eliminated or even extinct, so it must be inherited and preserved for the future generations. The values in folklore greatly contribute in maintaining the continuity of community life, creating a virtuous and charactered person, and can strengthen the resilience of national culture. The existence of folklore can be optimized in literature learning by using it as a learning resource. Folklore can stimulate the thoughts, feelings, attention, and interest of individuals to be involved in the learning process. In addition, the use of folklore also plays a role in preserving local culture and teaching values and norms of life. The habit of studying folklore with reading and writing activities will familiarize students with literacy activities. Literature is more interesting to read than lecture reference books. Thus, it is expected that the enjoyment of literary works can be the beginning of increasing interest for reading and writing activities which in turn develops literacy culture among students.

\section{References}

[1] N. Yachina, "The Problem of Spiritual and Moral Formation of Personality," Procedia - Soc. Behav. Sci., vol. 197, no. February, pp. 1575-1579, Jul. 2015, doi: 10.1016/j.sbspro.2015.07.113.

[2] E. S. Tevdovska, "Literature in ELT Setting: Students - Attitudes and Preferences Towards Literary Texts," Procedia - Soc. Behav. Sci., vol. 232, no. April, pp. 161-169, Oct. 2016, doi: 10.1016/j.sbspro.2016.10.041.

[3] T. Ayala-Perez and J. Joo-Nagata, "The digital culture of students of pedagogy specialising in the humanities in Santiago de Chile," Comput. Educ., vol. 133, no. June, pp. 1-12, May 2019, doi: 10.1016/j.compedu.2019.01.002.

[4] K. Saddhono, "Integrating Culture in Indonesian Language Learning for Foreign Speakers at Indonesian Universities," J. Lang. Lit., vol. 6, no. 2, pp. 349-353, 2015.

[5] R. Constantine, "Folklore and Legends," Encycl. Mar. Mamm., pp. 447-449, 2009, doi: 10.1016/B978-0-12-373553-9.00106-1.

[6] I. Al-Jubari, A. Mosbah, Z. Talib, A. Sulaiman, and Y. A. Jamal, "How Does Culture Shape Entrepreneurial Behaviours?," Int. J. Innov. Creat. Chang. www.ijicc.net, vol. 5, no. 2, pp. 967 980, 2019.

[7] A. C. Martin, "The Use of Film, Literature, and Music in Becoming Culturally Competent in Understanding African Americans," Child Adolesc. Psychiatr. Clin. N. Am., vol. 14, no. 3, pp. 589-602, Jul. 2005, doi: 10.1016/j.chc.2005.02.004. 
[8] M. Brown, C. Henchoz, and T. Spycher, "Culture and Financial Literacy," SSRN Electron. J., 2017, doi: 10.2139/ssrn.2916636.

[9] S. Pastore and H. L. Andrade, "Teacher assessment literacy: A three-dimensional model," Teach. Teach. Educ., vol. 84, pp. 128-138, Aug. 2019, doi: 10.1016/j.tate.2019.05.003.

[10] N. B. Afini Normadhi, L. Shuib, H. N. Md Nasir, A. Bimba, N. Idris, and V. Balakrishnan, "Identification of personal traits in adaptive learning environment: Systematic literature review," Comput. Educ., vol. 130, pp. 168-190, Mar. 2019, doi: 10.1016/j.compedu.2018.11.005.

[11] A. D. Arbona and S.-M. Chireac, "Romanian Folk Literature in Our Classes: A Proposal for the Development of Intercultural Competence," Procedia - Soc. Behav. Sci., vol. 178, no. November 2014, pp. 60-65, Apr. 2015, doi: 10.1016/j.sbspro.2015.03.147.

[12] Sutaryanto and A. Kartikasari, "Summary for Policymakers," in Climate Change 2013 - The Physical Science Basis, vol. 1, Intergovernmental Panel on Climate Change, Ed. Cambridge: Cambridge University Press, 2016, pp. 1-30.

[13] C. Lan and S. Fan, "Developing classroom-based language assessment literacy for in-service EFL teachers: The gaps," Stud. Educ. Eval., vol. 61, no. 8, pp. 112-122, Jun. 2019, doi: 10.1016/j.stueduc.2019.03.003.

[14] M. Schrijvers, T. Janssen, O. Fialho, S. De Maeyer, and G. Rijlaarsdam, "Transformative Dialogic Literature Teaching fosters adolescents' insight into human nature and motivation," Learn. Instr., vol. 63, no. May, p. 101216, Oct. 2019, doi: 10.1016/j.learninstruc.2019.101216. 